\title{
Wolves (Canis lupus) in the Torun Basin (N Poland): actual status and problems concerning the population
}

\author{
Piotr Sewerniak
}

\author{
Nicolaus Copernicus University, Faculty of Earth Sciences, \\ Department of Soil Science and Landscape Management, \\ Lwowska 1, 87-100 Torun, Poland, \\ e-mail: sewern@umk.pl
}

\begin{abstract}
The characteristics on the present wolf population of the Torun Basin were presented in the paper. The subject was introduced in terms of main ecological issues on Canis lupus as well as current problems in man-wolf relations occurring in the region. Forests of the Torun Basin are populated by 25-30 resident wolves which actually live in five packs. For some last seasons the predators have reproduced what is probably the main reason for stated slight increase in wolf number in the region. The major actual threats to local wolf population were indicated: pouching, car traffic and illegal off-road motor activity. In July 2014, the first for the 21 st century documented wolf attacks on domestic ungulates were stated in the Torun Basin when two unprotected from predators cow calves were bite near the Rafa village (NE of Bydgoszcz).
\end{abstract}

Key words: Canis lupus, large predators, wolf recovery, forests, Poland.

\section{Introduction}

The Torun Basin (ca. $1800 \mathrm{~km}^{2}$ ) is characterized by high part of forests in land use what predisposes the region for occurrence of wolves (Canis lupus). In former times the species almost constantly populated forests of the Basin; however after the Second World War for some decades number of wolves distinctly decreased what concerned the whole territory of Poland (Okarma, 1992). It was the result of "the wolf action" mainly which was initiated in 1950s and aimed at radically decreasing number of wolves in Poland (Kowalski, 1953; Okarma, 1992). As a result of almost twenty years of consequently and obstinate controlling, in 1966 the species was totally extirpated in forests of the Toruń Basin (Mastyński, 1967). From 1970s to 1990s there was no resident wolf population in any part of the Torun Basin and for these years only short-periodic occurrences of usually single wolves were reported for the region (Andrzejewski \& Wołk, 1991; Sewerniak, 2010). The situation has distinctly changed after 1998 since when Canis lupus has become fully protected species in Poland. It entailed consequently spreading of wolf range from eastern part of the country being the traditional Polish refuge of the species to other regions (Jędrzejewski et al., 2002; Nowak \& Mysłajek, 2011). The recolonization process concerned also forests of the Torun Basin in which the resident wolf population has occurred since the turn of the 20th and 21st. centuries (Krzemień, 2008; Sewerniak, 2008, 2010; Kamiński et al., 2011; Kulik \& Kamiński, 2014).

Data concerning facts on former wolf occurrence in the Torun Basin as well as characteristics on the 21 st. century wolf population in the region were introduced in the earlier paper (Sewerniak, 2010); however Canis lupus is the species which distinctly and incessantly raises human interests and emotions (often quite extreme and radical) so presenting actual data on the species is advisable and expected. Thus, the aim of the paper was to show the main current records and characteristics concerning present wolf popu- 
lation of the Torun Basin with reference both to ecological issues as well as to actual problems in man-wolf relations.

\section{Study area and methods}

The researches were conducted in forests of the Torun Basin in two big forest areas mainly: the Bydgoszcz Forest located on the left Vistula bank and the Dobrzejewice Forest situated right (NE) of the River. The main base for the presented in the article data was long-term, whole yearly observations and followings of the article's author. The gathered data were broadened and supplemented by information gained from local foresters, scientists, hunters and enthusiasts what concerned facts on wolves populated the Dobrzejewice Forest and the western part of the Bydgoszcz Forest mainly.

\section{Results and discussion}

The present number of wolves in the Torun Basin is estimated for 25-30 resident individuals which live in 5 packs: 3 packs (ca. 17 wolves) occupy the Bydgoszcz Forest and 2 (ca. 10 predators) the Dobrzejewice Forest. These values indicate the slight increase of wolf number in the Torun Basin which can be stated for some last years. The increase is caused by wolf reproduction in the region mainly; however not in all 5 packs pups have been born in each of last years. For most last years reproduction was stated for 3 packs ( 2 from the Bydgoszcz Forest and 1 from the Dobrzejewice Forest) while for 2 family groups it was not evidenced. Besides, these 2 packs have been only lately formed so data concerning issues on their ecology has not been well recognized.

The increase of wolf number has resulted in happened observations of the predators in adjacent to the Torun Basin forests of minor areas in which wolves has not been seen even for some last decades. It has appeared since 2014 mainly that transition several occurrences of wolves were stated e.g. for a forest located between Bydgoszcz and Unisław and for a forest situated east of Inowrocław (near the Rejna village).

As it is typical for wolves, in late autumn and at winter time they often gather in more numerous packs, thus in these seasons it has been possible to meet a wolf pack consisted of even ca. 15 individuals in the Torun Basin (Fig. 1). A pack is formed then by local wolves, but, as it can be stated on the basis of field observations, some migrating individuals can likely be temporarily tolerated to join a group for some months. Later, foreign wolves are usually kept for a distance to a pack what is achieved e.g. thanks to scent marking a pack territory by dominant individuals with urine (Fig. 2).

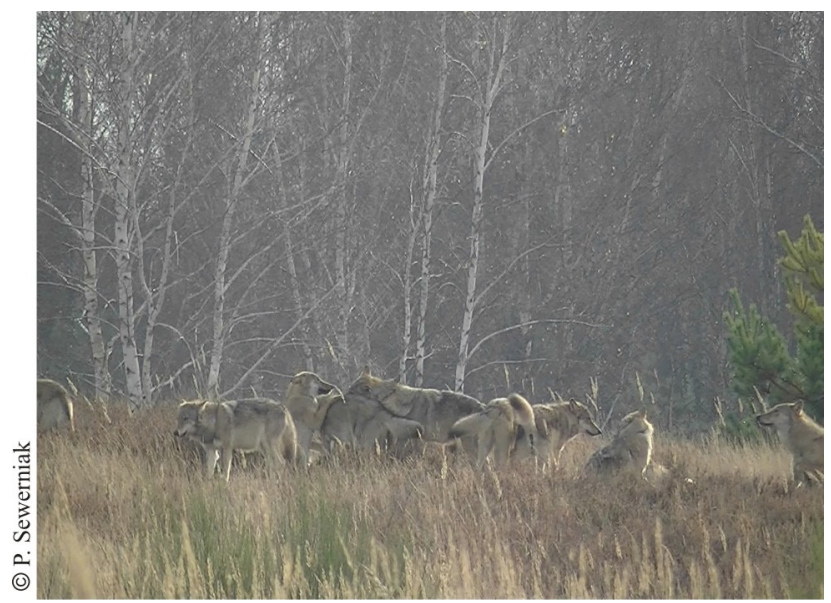

Figure 1. A pack of "Ruda", autumn 2013

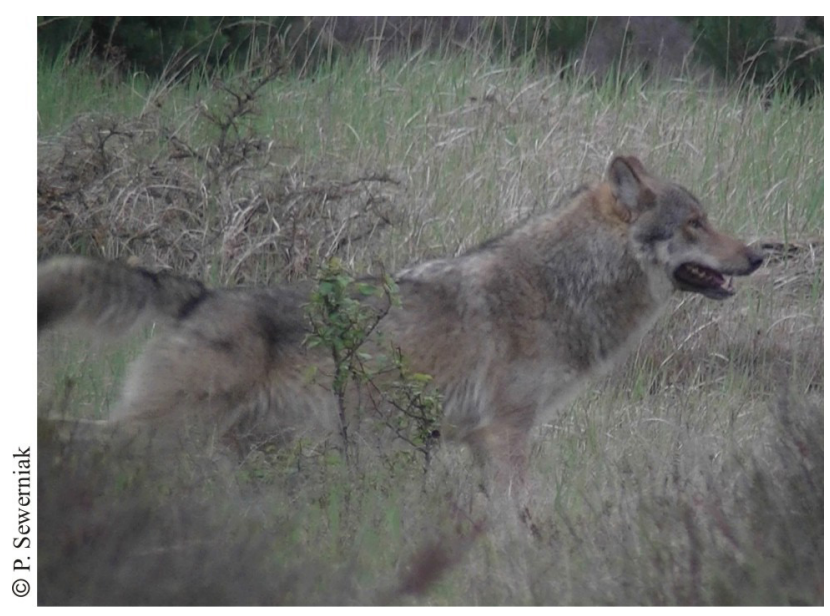

Figure 2. A dominant male wolf scent marking a territory with urine

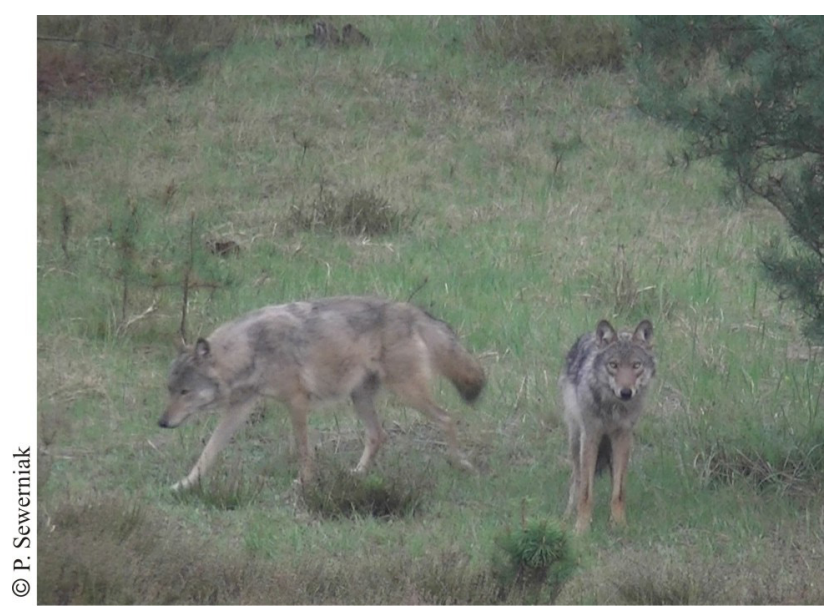

Figure 3. A pregnant, dominant wolf ("Chinka", left) and a young individual, spring 2010 


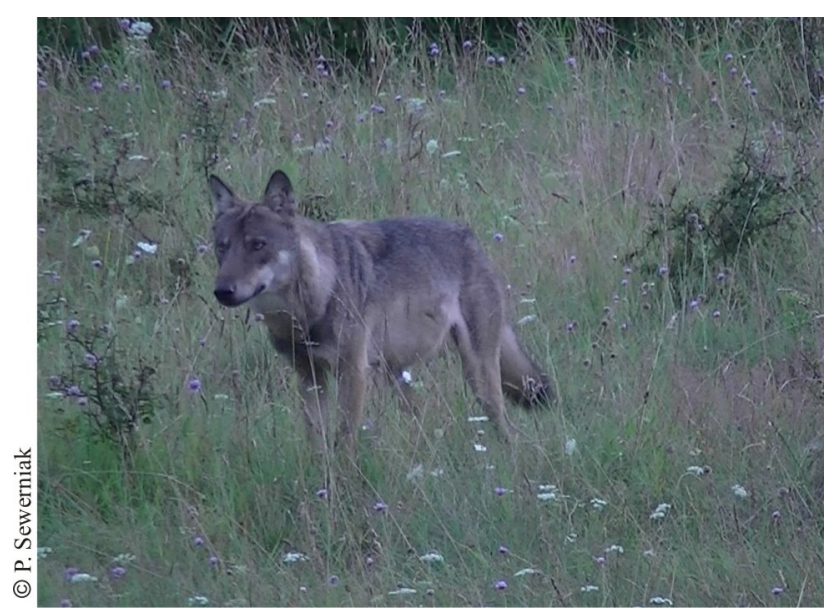

Figure 4. "Chinka" in summer 2011

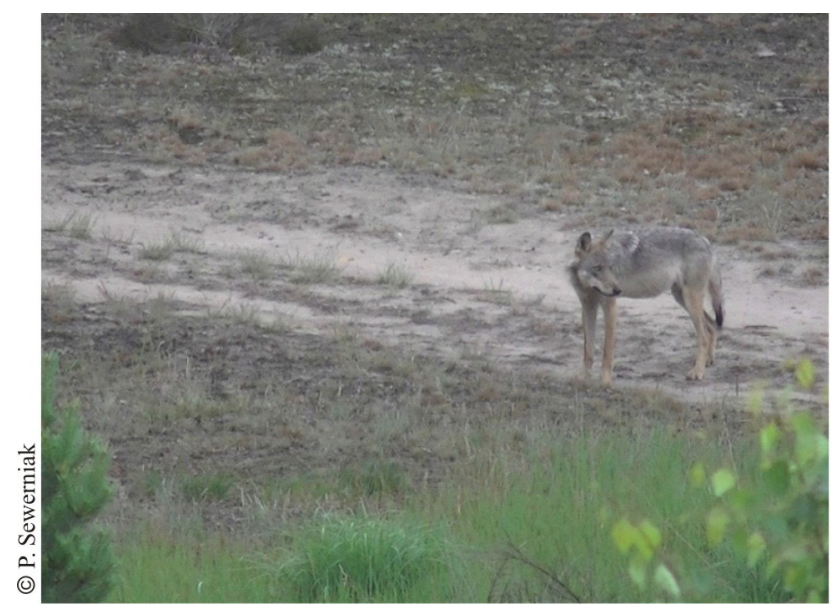

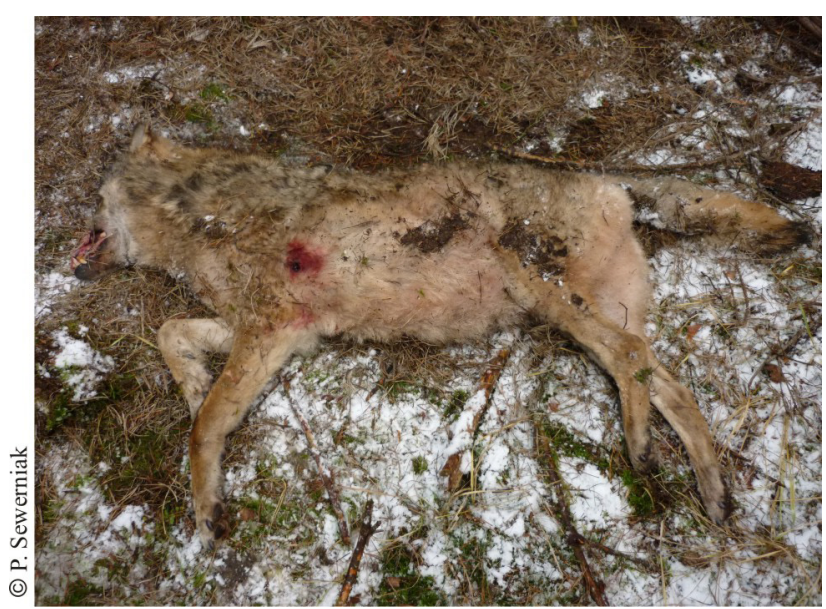

Figure 5. "Chinka" pouched in January 2013

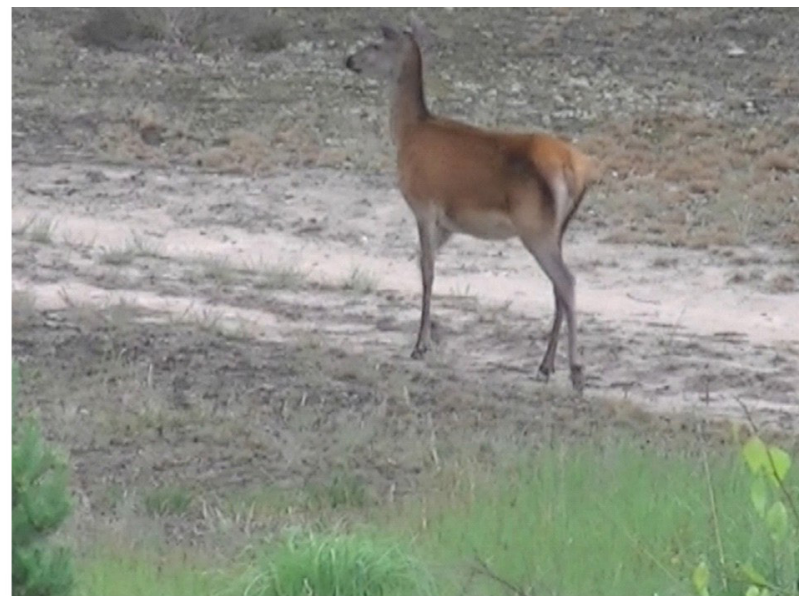

Figure 6. A wolf and a deer hind looking at each other from a distance of ca. $50 \mathrm{~m}$ (the photos were taken at interwal of ca. 2 minutes; finally a hind followed a wolf to the left)

After more than decade of conducting regular and permanent researches on Canis lupus in the Torun Basin it has been possible to know histories of individual wolves of the population. For example it was found that especially important contribution to the increase of wolf number in the studied region and probably also to wolf "come back" to Western Poland brought a female called "Chinka". For at least 3 seasons (2010-2012) she was a dominant female and reproduced in a pack which occupied the eastern part of the Bydgoszcz Forest (Figs 3, 4); however, at the age of 8-9 years the wolf was pouched with a firearm in January 2013 (Fig. 5). In spite it was the only revealed case of pouching on wolves in the Torun Basin in the 21 st century, other, unrevealed such events were of high probability. The unfavour circumstance for wolves of the Torun Basin is the fact that $69 \%$ of local hunters consider the species as unwanted one in forests of the region (Kamiński et al., 2011).
This aversion appears e.g. in their lobbying for restoring hunting for wolves in the Torun Basin (e.g. Łogin, 2007) in spite the predators do not constitute a serious competition for interests of hunters in the region. As it was indicated by Kamiński et al. (2011), for the period since wolves recolonized the Bydgoszcz Forest number of all 3 basic game ungulate species living in the Forest (red deer Cervus elaphus, roe deer Capreolus capreolus and wild boar Sus scro$f a$ ) has increased even though at this time number of these animals harvested by hunters has also increased! From the other hand, analysis of structure of wolf preys on the basis of carcasses found indicates that wolf predation have not constituted serious threat to interest of hunters also in aspect of "quality" of killed animals. As it was reported by all authors who investigated wolf preys in the Torun Basin on the basis of found remnants of hunted animals (Krzemien, 2008; Sewerniak, 2008, 2010; Kamiński et al., 2011) the 
Table 1. Some characteristics concern dead wolves found in the Torun Basin in the 21st century (Sewerniak 2010, completed)

\begin{tabular}{|c|c|c|c|c|c|c|}
\hline $\begin{array}{l}\text { Date of an } \\
\text { accident }\end{array}$ & $\begin{array}{l}\text { Location } \\
\text { Forest Division }\end{array}$ & Forest District & Compartment number & $\begin{array}{l}\text { Cause of } \\
\text { death }\end{array}$ & Sex & $\begin{array}{l}\text { Approx. age } \\
\text { (years) }\end{array}$ \\
\hline 17.11.2005 & Cierpiszewo & Chorągiewka & 252 & $\mathrm{CA}$ & $\hat{0}$ & $3-4$ \\
\hline 02.02 .2006 & Gniewkowo & Zajezierze & 114 & $\mathrm{CA}$ & q & $2-3$ \\
\hline 14.05.2009 & Gniewkowo & Karczemka & 251 & $\mathrm{CA}$ & 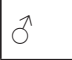 & 1 \\
\hline 28.05 .2011 & Cierpiszewo & Chorągiewka & 140 & CA & 0 & $5-6$ \\
\hline 19.10 .2012 & Gniewkowo & Rudak & 48 & CA & q & 1 \\
\hline 01.2013 & Gniewkowo & Popioły & 437 & $\mathrm{P}$ & q & $8-9$ \\
\hline
\end{tabular}

Abbreviations: $\mathrm{CA}$ - car accident, $\mathrm{P}$ - pouching

predators evidently selected as preys defective individuals, females and juvenile ungulates so animals of usually very low trophy value and thus being of low interests for most of present-day hunters. Similar selective pattern of wolf preys is well known and was reported also for other regions of Poland (e.g. Jędrzejewski et al., 1992, 2000; Śmietana \& Klimek, 1993).

Predators and their potential preys live together as neighbors in the same forests and animals which are in good condition normally has not reasons to avoid wolves in panic (Fig. 6) as well as wolves do not aim at killing as many ungulates as possible. Unfortunately, this what for a long time has been already obvious for scientists still remains misunderstood by some lobbying hunters who present a wolf as species tending to exterminate other forest animals (Login, 2007).

It is interesting that a geographical pattern in wolf predation can be found in the Torun Basin which reflects attainability of prey species. Based on remnants of preys found as well as field analyses of wolf scats it can be stated that in long time perspective red deer is evidently the main wolf prey in the Torun Basin; however as it was found by Nowak et al. (2011) roe deer can periodically prevail in diet of the predators in the region. Although the dominance of Cervus elaphus in wolf diet was widely reported in literature (Jędrzejewski et al., 1992; Śmietana \& Klimek 1993; Jędrzejewski et al. 2000; Nowak et al. 2005; Kamiński et al. 2011) an opportunistic character of Canis lupus predation is highlighted (Okarma, 1992). It appears not only in selection, if only possible, as preys animals of poor condition but also in bias of species consumed with their relative abundance in community (e.g. Nowak et al., 2011). It reflects also in the Torun Basin where wild boar is relatively often killed by wolves in the Dobrzejewice Forest in which the ratio of number of Sus scrofa to red deer population is much higher than in the Bydgoszcz Forest.

Besides intentional eliminating wolves by pouching the other main threat to the species in the Torun Basin is car traffic since wolf territories are crossed by some busy roads there. In the last decade at least 5 wolves from the present population has already been killed in car accidents. The all documented in the 21st century dead wolves found in the Torun Basin were listed and characterized in the table 1. One more major threat to wolves in the region is illegal off-road motor activity (Sewerniak, 2010) which regularly causes anxiety in refuges of animals. The problem of this activity which evidently negatively affects different components of ecosystems has not been efficiently solved in whole Poland yet.

The increase in number of wolves and succeeding repetitively visits of the predators in adjacent to the Torun Basin minor forest areas in which they have not been seen for many decades implies some new for the region conflicts in man-wolf relations. Namely, events of elimination of feral dogs which happened close to villages are reported what could increase aversion of people to wolves. Moreover, in July 2014, wolf attacks on domestic ungulates were reported in the region. Both of them happened near the Rafa village located between Bydgoszcz and Unisław, close to the Vistula River, where wolves bite two cow calves. They were stayed lonely at nights, neither fenced nor protected by pastoral dogs. In spite these incidents have been the only wolf attacks for domestic ungulates recorded in the Torun Basin in the 21 st century they clearly showed that local farmers were not prepared for animal husbandry when wolves have recolonized adjacent forests. If such attacks repeat in the future it will be advisable to instruct local farmers how to imply effective methods to protect livestock from wolves what would enable to reduce man-wolf conflicts.

\section{Acknowledgments}

The author is grateful to all who help to gather data on wolves living in the Torun Basin. Special words of praise 
are addressed to those who make efforts to increase man tolerance to wolves and to mitigate potential man-wolf conflicts.

\section{References}

Andrzejewski H. \& Wołk K., 1991, Wilk Canis lupus L. w okolicach Torunia [Wolf Canis lupus L. in the neighbourhood of Toruń], Przegl. Zoologiczny, 35: 393-396.

Jędrzejewski W., Jędrzejewska B., Okarma H. \& Ruprecht A.L., 1992, Wolf predation and snow cover as mortality factors in the ungulate community of the Białowieża National Park, Poland, Oecologia, 90: 27-36.

Jędrzejewski W., Jędrzejewska B., Okarma H., Schmidt K., Zub K. \& Musiani M., 2000, Prey selection and predation by wolves in Białowieża Primeval Forest, Poland, Journal of Mammalogy, 81: 197-212.

Jędrzejewski W., Nowak S., Schmidt K. \& Jędrzejewska B., 2002, Wilk i ryś w Polsce - wyniki inwentaryzacji w 2001 roku [The wolf and the lynx in Poland - results of a census conducted in 2001], Kosmos, 51: 491-499.

Kowalski Z., 1953, Wilk i jego zwalczanie [Wolf and its controlling], Państwowe Wydawnictwo Rolnicze i Leśne, Warszawa.

Kamiński B., Fiderewicz J. \& Grajewski S., 2011, Wilk (Canis lupus L.) w Puszczy Bydgoskiej i jego wpływ na populacje dziko żyjących zwierząt kopytnych [Wolf (Canis lupus L.) in Bydgoszcz Forest and its impact on populations of wild ungulates], Infrastruktura i Ekologia Terenów Wiejskich, Kraków, 2: 247-260.

Krzemień Z., 2008, Wilcze powroty [Wolves' come backs], Nemrod, Kwartalnik Okręgowej Rady Łowieckiej w Bydgoszczy, 1 (30): 4-8.
Kulik M. \& Kamiński D., 2014, Application of GIS technology in the analysis of wolf Canis lupus L. behaviour and migration routes in the landscape, Ecological Questions, 19: 67-71.

Łogin M., 2007, Wilki u wrót miasta [Wolves in a city gate], Łowiec Polski, 1: 20-21.

Mastyński Z., 1967, Fauna Województwa Bydgoskiego wzbogaca się w ostatnich latach [Fauna of the Bydgoszcz Province has been enriched for some years], Wrzechświat, 12(1993): 295-297.

Nowak S., Mysłajek R., 2011, Wilki na zachód od Wisły [Wolves west of the Vistula River], Stowarzyszenie dla Natury „Wilk”, Twardorzeczka.

Nowak S., Mysłajek R.W. \& Jędrzejewska B., 2005, Patterns of wolf Canis lupus predation on wild and domestic ungulates in the Western Carpathian Mountains (S Poland), Acta Theriologica, 50: 263-276.

Nowak S., Mysłajek R.W., Kłosińska A., Gabryś G., 2011, Diet and prey selection of wolves (Canis lupus) recolonizing Western and Central Poland, Mammalian Biology, 76: 709-715.

Okarma H., 1992, Wilk. Monografia przyrodniczo-łowiecka [Wolf. Nature-game monographs.], Białowieża.

Sewerniak P., 2008, Wilki w Puszczy Bydgoskiej [Wolves in the Bydgoszcz Primeval Forest], Las Polski, 1: 1415.

Sewerniak P., 2010, Wolves in the Torun Basin, Ecological Questions, 13: 47-53.

Śmietana W. \& Klimek A., 1993, Diet of wolves in the Bieszczady Mountains, Poland, Acta Theriol., 38: 245251 . 